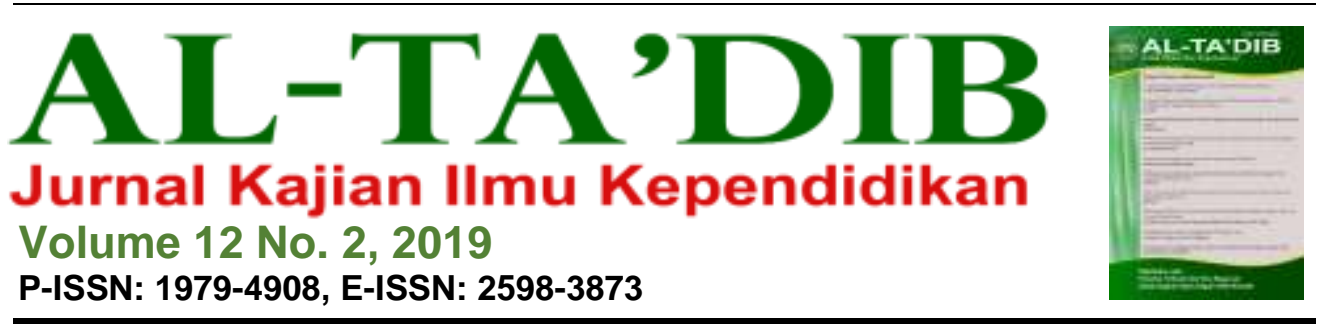

\title{
Studi Korelasional Perilaku Kepemimpinan dan Iklim Kerja dengan Prestasi Kerja Guru Sekolah Menengah Atas
}

\author{
Mansyur ${ }^{1}$ \\ ${ }^{1}$ Institut Agama Islam Negeri Kendari, Kendari, Indonesia. E-mail: mansyurdrmpd@gmail.com
}

\begin{tabular}{l} 
INFORMASI ARTIKEL \\
\hline Kata Kunci: \\
Iklim kerja; perilaku \\
kepemimpinan; prestasi \\
kerja \\
Cara Mensitasi: \\
Mansyur. (2019). Studi \\
korelasional perilaku \\
kepemimpinan dan iklim \\
kerja dengan prestasi kerja \\
guru sekolah menengah \\
atas. Al-Tadib:Jurnal \\
Kajian Ilmu Kependidikan, \\
12(2), 277-293 \\
DOI: \\
http://dx.doi.org/10.31332/ \\
atdbwv12i2.1334
\end{tabular}

\begin{abstract}
ABSTRAK
Penelitian kuantitatif ini bertujuan untuk mengetahui korelasi perilaku kepemimpinan dan iklim kerja dengan prestasi kerja guru sekolah menengah atas. Penelitian ini menggunakan metode survei dengan pendekatan korelasional terhadap 51 orang guru sebagai sampel yang dipilih secara acak.. Hasil penelitian menunjukkan bahwa perilaku kepemimpinan kepala sekolah dalam mengendalikan sekolah berhubungan erat dengan prestasi kerja guru. Iklim kerja yang kondusif dan menyenangkan merupakan salah satu prediktor prestasi kerja guru. Perilaku kepemimpinan dan iklim kerja secara bersamasama merupakan prediktor prestasi kerja guru. Hasil penelitian ini mengidikasikan bahwa untuk mewujudkan prestasi kerja guru yang lebih baik maka perilaku kepemimpinan dan iklim kerja sebagai faktor penentu harus diperhatikan. Jika seorang kepala sekolah memiliki perilaku kepemimpinan dan iklim kerja yang positif dan kondusif maka prestasi kerja guru akan cenderung meningkat, sebaliknya jika seorang kepala sekolah memiliki perilaku kepemimpinan dan iklim kerja yang negatif dan tidak kondusif maka prestasi kerja guru akan cenderung menurun.
\end{abstract}




\section{ARTICLE INFO}

Keywords:

Leadership behavior; work

climate; work performance

How to cite:

Mansyur. (2019). Studi

korelasional perilaku

kepemimpinan dan iklim

kerja dengan prestasi kerja

guru sekolah menengah

atas. Al-Tadib:Jurnal

Kajian Ilmu Kependidikan, 12(2), 277-293

\section{DOI:}

http://dx.doi.org/10.31332/

atdbwv12i2.1334

\begin{abstract}
This correlational study aims to reveal the relationships between leadership behavior and work climate with performance of senior high school teacher. Using survey method, questionnaires were administered to 51 senior high school teachers as sample who were selected randomly. The result of this study shows that the headmaster's leadership behavior in controlling the school is closely related to the teacher's work performance. Conducive and enjoyable work climate is one of prediction measurement of teacher's work performance. Leadership behavior and work climate are the prediction measurement of teacher's work performance. This study indicates that in order to realize better teacher's work performance, leadership behavior and work climate should be of consideration. If a headmaster has positive leadership behavior and conducive work climate, the tacher's work performance tends to increase. On the contrary, if a headmaster shows negative leadership behavior and non-conducive work climate, the teacher's work performance tends to decrease.
\end{abstract}

\section{Pendahuluan}

Kepemimpinan dan iklim kerja merupakan dua hal yang berbeda meskipun memiliki tautan dalam konteks kerja dan interaksi antara manusia secara organisasional. Dengan demikian, tanpa kepemimpinan sebuah organisasi hanya akan merupakan kelompok manusia yang tidak teratur dan tidak akan melahirkan perilaku bertujuan (Hersey \& Blanchard, 1990). Kepemimpinan adalah faktor manusia yang mengikat suatu kelompok bersama dan memberinya motivasi untuk mencapai tujuan tertentu. Iklim kerja juga memengaruhi prestasi kerja. Iklim kerja kondusif akan mengakibatkan prestasi kerja yang tinggi. Sebaliknya, iklim kerja yang tidak baik akan menurunkan prestasi kerja. Dalam lingkup sekolah, misalnya, guru yang bekerja pada kondisi iklim kerja yang menyenangkan akan memiliki kinerja yang baik. Ia akan dapat meningkatkan prestasi kerjanya dalam bidang pendidikan.

Kepemimpinan dalam bidang pendidikan harus bisa membangkitkan inspirasi guru, menciptakan kerja sama antar guru, antar staf, mengembangkan program supervisi, mengelola kegiatan program pengembangan, dan 
melaksanakan kegiatan-kegiatan yang erat kaitannya dengan pengembangan tujuan pendidikan (Nurdin, 2005). Kemampuan mengorganisasi dan membantu staf, mengembangkan dan memupuk rasa percaya diri, membangkitkan sikap kerjasama, memberi bimbingan dan tuntunan untuk mencapai tujuan pendidikan yang efektif dan efisien adalah kebutuhan yang sangat mendesak dalam kepemimpinan pendidikan.

Tugas guru meliputi mendidik, mengajar dan melatih. Mendidik berarti meneruskan dan mengembangkan nilai-nilai hidup. Mengajar berarti meneruskan dan mengembangkan ilmu pengetahuan dan teknologi. Selanjutnya, melatih berarti mengembangkan keterampilan pada siswa. Tugas guru dalam bidang kemanusiaan di sekolah harus dapat menjadikan dirinya sebagai orang tua kedua. Pelajaran apapun yang diberikan, hendaknya menjadi motivasi bagi siswanya dalam belajar. Bila seorang guru yang dalam penampilannya sudah tidak menarik, maka kegagalan yang pertama adalah ia tidak akan dapat menanamkan benih pengajarannya itu kepada para siswanya. Para siswa akan enggan menghadapi guru yang tidak menarik (Usman, 2000)

Tugas dan peran guru pada hakikatnya merupakan komponen strategis yang memilih pesan penting dalam menentukan gerak maju kehidupan bangsa. Bahkan keberadaan guru merupakan faktor yang tidak mungkin digantikan oleh komponen manapun dalam kehidupan bangsa. Keberadaan guru bagi suatu bangsa amatlah penting bagi keberlangsungan hidup bangsa di tengahtengah lintasan perjalanan zaman dengan teknologi yang kian canggih. Segala perubahan serta pergeseran nilai cenderung memberi nuansa kepada kehidupan yang menuntut ilmu dan seni dalam kadar dinamik untuk dapat mengadaptasikan diri. Semakin akurat peran guru dalam melaksanakan fungsinya, semakin tercipta dan terbina kesiapan dan keandalan seseorang sebagai manusia pembangunan. Dengan kata lain, potret dan wajah diri bangsa di masa depan tercermin dari potret diri para guru masa kini, dan gerak maju kehidupan bangsa berbanding lurus dengan citra para guru di tengah-tengah masyarakat.

Proses pendidikan merupakan proses perubahan sesuatu menjadi lebih baik. Hal tersebut berpengaruh terhadap berlangsungnya proses yang disebut input, sedang sesuatu dari hasil proses disebut ouput. Dalam pendidikan berskala mikro (tingkat sekolah), proses yang dimaksud meliputi proses pengelolaan kelembagaan, proses pengelolaan program, proses belajar mengajar (Hardiyanto \& Subijanto, 2003). Selama 43 tahun perjalanan Sulawesi Tenggara, aspek pendidikan dari segi sarana prasarana cukup berkembang. Namun, dari segi kualitas, pendidikan Sulawesi Tenggara cukup tertinggal jauh. Daya saing lulusan SMA untuk masuk pada perguruan tinggi terkemuka di Indonesia cukup rendah. Begitu pula dengan nilai ujian nasional (UN) yang masih rendah. Contoh nyata lainnya, persaingan sumber daya manusia (SDM) Sulawesi Tenggaara dalam akses lapangan kerja juga masih 
kalah dari daerah lain. Faktor utama penyebab rendahnya indeks kualitas SDM dari segi pendidikan antara lain pengelolaan/manajemen sekolah belum efektif, kualitas tenaga pengajar masih rendah serta motivasi belajar siswa yang masih minim.

Hasil pengamatan dan informasi yang diperoleh dari pihak terkait (stakeholder) sekolah mengindikasikan bahwa mutu pembelajaran di SMA dan MA belum mencapai tingkat yang memuaskan akibat kompetensi mengajar guru yang belum maksimal. Beberapa hal yang dapat menggambarkan kondisi tersebut antara lain kurang siapnya guru dalam melakukan kegiatan pembelajaran, kurangnya penguasaan keterampilan menggunakan berbagai metode mengajar, kurangnya kemampuan menyusun alat evaluasi serta kemampuan menangani masalah belajar siswa.

Prestasi kerja guru merupakan salah satu penyebab keberhasilan penyelenggaraan pendidikan di sekolah. Namun demikian, prestasi kerja guru sangat tergantung pada sejumlah faktor, antara lain adalah perilaku kepemimpinan kepala sekolah, iklim kerja dan faktor-faktor lain. Sehubungan dengan pemikiran dan kondisi tersebut, penulis memandang perlu untuk melakukan penelitian tentang korelasi antara perilaku kepemimpinan dan iklim kerja dengan prestasi kerja guru, dengan melakukan survei pada guru SMA di Kota Kendari. Permasalahan ini penting untuk dikaji dalam rangka meningkatkan kualitas pengelolaan pendidikan di Kota Kendari pada masa yang akan datang.

\section{Prestasi Kerja}

Prestasi kerja adalah suatu hasil kerja yang dicapai seseorang dalam melaksanakan tugas-tugas yang dibebankan kepadanya yang didasarkan atas kecakapan, pengalaman, dan kesungguhan. Prestasi kerja merupakan gabungan dari tiga faktor penting, yaitu kemampuan dan minat seorang pekerja, kemampuan dan penerimaan atas penjelasan delegasi tugas, serta pesan dan tingkat motivasi seorang pekerja. Semakin tinggi ketiga faktor diatas, semakin besarlah prestasi kerja karyawan (guru) bersangkutan (Usman, 2000).

Kerja adalah pengembangan jasa-jasa, jasmani dan pikiran untuk menghasilkan barang-barang atas jasa dengan memperoleh imbalan prestasi tertentu. Semangat kerja adalah keinginan dan kesanggupan seseorang mengerjakan pekerjaannya dengan baik serta berdisiplin untuk mencapai prestasi kerja yang maksimal. Semangat kerja ini akan merangsang seseorang untuk berkarya dan berkreatifitas dalam pekerjaannya. Produktivitas kerja adalah perbandingan antara output dengan input.

Sardiman dalam Nurdin (2005) mengemukakan bahwa prestasi kerja guru dalam merencanakan dan mendesain program pengajaran terkait dengan penguasaan sepuluh kompetensi guru. Kesepuluh kompetensi tersebut 
meliputi kemampuan: 1) menguasai bahan, 2) mengelola program pembelajaran, 3) melaksanakan program belajar mengajar, 4) mengenal kemampuan anak didik, 5) menguasai landasan-landasan kependidikan, 6) mengelola interaksi belajar mengajar, 7) menilai prestasi siswa untuk kepentingan pengajaran, 8) mengenal fungsi dan program bimbingan dan penyuluhan di sekolah, 9) mengenal dan menyelenggarakan administrasi sekolah, dan 10) memahami prinsip dan penafsiran hasil penelitian pendidikan untuk keperluan pengajaran.

Senada dengan hal tersebut, Abdurrahman (1993) mengatakan bahwa untuk melakukan tugas pokoknya, guru harus memiliki seperangkat kompetensi keguruan antara lain: 1) penguasaan materi bidang studi yang diajarkan, 2) pemahaman dan keterampilan mengelola kelas, 3) pemahaman dan kemampuan mengelola program pengajaran dan proses belajar mengajar, 4) keterampilan memilih dan menggunakan berbagai media pembelajaran, 5) kemampuan dan keterampilan memilih dan menggunakan model-model pembelajaran bervariasi, 6) kemampuan dan keterampilan menerapkan prinsip-prinsip pengukuran dan penilaian, 7) pengetahuan, pemahaman, dan kemampuan menerapkan pengembangan sistem-sistem dalam proses belajar mengajar, serta 8) pengetahuan, pemahaman, dan keterampilan menyusun dan melaksanakan konseling di sekolah. Dengan demikian, jelas bahwa gurulah yang memegang kunci utama dalam menghasilkan dan meningkatkan mutu pendidikan. Kelancaran kegiatan pengajaran atau proses belajar mengajar dilihat dari tercapainya tujuan untuk menghasilkan keluaran yang telah belajar atau siswa yang telah mengalami perubahan ke arah tercapainya kedewasaan.

Kemampuan mengajar sebagai bagian dari kompetensi keguruan mencakup kemampuan atau keterampilan yang harus dikuasai oleh seorang guru dalam mengelola belajar mengajar serta dapat menggambarkan profesionalismenya dalam bidang kependidikan. Kemampuan guru sebagai tenaga profesional, baik sebagai pendidik maupun pengajar, merupakan kemampuan yang pada umumnya berhubungan dengan pengetahuan, keterampilan, dan sikapnya sebagai seorang guru (Usman, 2000). Guru sebagai pengajar perlu memiliki pengetahuan, keterampilan dan sikap tentang mengajar di kelas secara efektif dan efisien, khususnya kemampuan dalam hal merencanakan program pengajaran, merumuskan tujuan pengajaran, kemampuan dan penguasaan materi pelajaran, serta kemampuan memilih metode mengajar secara tepat, kemampuan mengevaluasi hasil belajar, dan lain-lain (Azhari, 2003).

Sementara itu, Usman (2000) mengemukakan dua jenis kompetensi guru, yaitu kompetensi pribadi dan kompetensi profesional. Senada dengan hal tersebut, Soedjiarto (1993, dalam Azhari 2003) mengemukakan bahwa terdapat tujuh kemampuan yang harus dimiliki oleh guru prefesional, yaitu: 1) memahami peserta didik dengan latar belakang dan kemampuannya, 2) 
menguasai disiplin ilmu sebagai sumber bahan belajar, 3) menguasai bahan belajar, 4) memiliki wawasan kependidikan yang mendalam, 5) menguasai rekayasa dan teknologi pendidikan, 6) memahami tujuan dan filsafat pendidikan nasional, serta 7) berkepribadian dan berjiwa Pancasila.

Menurut Acheson dan Gall (dalam Azhari, 2003), ciri-ciri guru yang professional, yaitu: 1) memiliki hubungan yang positif dengan siswa, 2) memperhatikan atau peduli terhadap emosi siswa, 3) memelihara kedisiplinan, 4) menciptakan lingkungan yang nyaman atau kondusif untuk belajar, 5) mengenal dan memperhatikan perbedaan individual, 6) menikmati bekerja dengan siswa, 7) mengupayakan keterlibatan siswa dalam belajar, 8) kreatif dan inovatif, 9) menekankan keterampilan membaca, 10) memberi siswa image diri yang baik, 11) aktif dalam kegiatan-kegiatan pengembangan profesionalitas, 12) menguasai materi secara mendalam, 13) fleksibel, dan 14) konsisten.

Dari beberapa pendapat yang telah dikutip di atas, dapat disimpulkan bahwa prestasi kerja guru adalah hasil kerja nyata guru yang merupakan kombinasi dari faktor-faktor, antara lain: 1) kemampuan merencanakan pengajaran, 2) kemampuan mengelola kelas, 3) kemampuan melaksanakan kegiatan belajar mengajar, 4) melakukan penilaian hasil belajar siswa, 5) memiliki keterampilan memberi pertanyaan kepada siswa, 6) memiliki keterampilan memberi penguatan kepada siswa, 7) mengadakan variasi dalam mengajar, 8) memiliki keterampilan dalam menjelaskan materi pelajaran, 9) memiliki keterampilan dalam membuka dan menutup pelajaran, 10) membimbing siswa dalam KBM baik kelompok dan perorangan, serta 11) memiliki kemampuan mengembangkan unsur profesionalisme.

\section{Perilaku Kepemimpinan}

Perilaku (behavior) adalah operasionalisasi dan aktualisasi sikap seseorang atau suatu kelompok dalam suatu situasi dan kondisi. Perilaku mendapat pengaruh yang kuat dari motif kepentingan. Menurut Ndaraha (2003), perilaku dipengaruhi oleh kondisi yang datang dari luar seperti lingkungan oleh yang bersangkutan. Perilaku merupakan aktualisasi, sosialisasi dan internalisasi keyakinan, pendirian atau sikap.

Nawawi (2003) mengemukakan bahwa gaya atau perilaku kepemimpinan akan tampak dari cara melakukan pengambilan keputusan, memerintah atau memberi instruksi, memberi tugas, berkomunikasi, mendorong semangat bawahan, membimbing dan mengarahkan, menegakkan disiplin, mengendalikan dan mengawasi pekerjaan anggota organisasi, memimpin rapat, menegur, dan cara memberi sanksi. Sedangkan menurut Hersey dan Blanchard (1969), ciri-ciri seorang pimpinan dapat dijelaskan melalui tiga pendekatan yaitu kepemimpinan bawaan, kepemimpinan berperspektif perilaku, dan kepemimpinan situasional. Pendekatan pertama 
memandang kemampuan memimpin sebagai bawaan sejak lahir, yakni hanya orang-orang yang berbakat memimpin yang mampu menjadi pimpinan. Pendekatan kedua, kepemimpinan berperspektif perilaku, yaitu mempelajari kepemimpinan berdasarkan keterampilan yang dimiliki. Kepemimpinan yang berperspektif perilaku secara garis besar dapat dibagi dalam tiga kategori, yakni a) keterampilan teknik yang terkait dengan pengetahuan dan kemampuan seseorang dalam melakukan pekerjaan yang bersifat teknis; b) keterampilan manusiawi yang merupakan kemampuan seseorang dalam bekerja secara efektif dengan orang lain dan membangun tim kerja; dan, c) keterampilan konseptual adalah kemampuan seseorang berpikir dalam bentuk model-model, kerangka kerja, dan hubungan luas lainnya. Pendekatan ketiga, pendekatan situasional dibangun berdasarkan asumsi bahwa tidak ada satu cara apapun yang dapat mengarahkan manusia untuk bekerja pada semua situasi. Dengan demikian, pemimpin harus memiliki perilaku yang fleksibel, mampu mendiagnosis gaya kepemimpinan sesuai dengan situasi yang dihadapinya, dan mampu menerangkannya dalam situasi kepemimpinan sebenarnya.

Perilaku kepemimpinan mencerminkan apa yang dilakukan oleh pimpinan dalam memengaruhi pengikutnya untuk merealisasi visinya. Sebagian penulis mempergunakan istilah perilaku kepemimpinan (leadership behavior) dan sebagian lagi mempergunakan istilah gaya pimpinan (leader style). Pengertian perilaku kepemimpinan mempunyai konotasi yang sama dengan gaya pimpinan. Perilaku kepemimpinan mempunyai pengaruh ketika dipergunakan oleh pimpinan dalam kepemimpinan yaitu proses interaksi dengan para pengikutnya. Interaksi ini akan mempengaruhi pola perilaku pengikut yang disebut gaya kepengikutan (followership style) istilah perilaku kepemimpinan (leadership behavior).

Perilaku kepemimpinan adalah aktivitas yang biasa dikerjakan, diperbuat dan dikatakan oleh seseorang dalam mengendalikan dan mengarahkan orang lain. Adakalanya juga disebut pendekatan pimpinan dalam menggunakan kewenangannya untuk mempengaruhi para bawahannya. Pola perilaku yang dimaksud tidak dalam pengertian statis akan tetapi dalam pengertian dinamis. Perilaku kepemimpinan seorang pemimpin dapat berubah tergantung pada para pengikutnya dan situasinya. Dengan kata lain, seorang pemimpin dapat mempergunakan sejumlah pola perilaku yang berbeda dalam mempengaruhi para pengikutnya (Danim, 2004).

Berdasarkan beberapa pendapat yang telah dikutip di atas, perilaku kepemimpinan kepala sekolah adalah cara atau teknik yang biasa dikatakan, diperbuat, dan digunakan oleh kepala sekolah dalam menggunakan kewenangannya untuk memengaruhi para bawahannya. Perilaku kepemimpinan merupakan kombinasi sejumlah faktor, yaitu: 1) perilaku menganalisis karakteristik pengikut, 2) perilaku memiliki dan menggunakan 
kekuasaan, 3) perilaku memilih dan menggunakan teknik, dan 4) perilaku menggunakan karakteristik pribadi.

\section{Iklim Kerja}

Danim (2004) mengatakan bahwa iklim kerja lebih mengarah pada halhal yang bersifat non fisik, yaitu terkait dengan proses komunikasi, interaksi dan kerjasama dalam suatu organisasi. Iklim kerja adalah lingkungan manusia di mana para guru bekerja. Iklim kerja adalah persepsi guru tentang berbagai aspek yang ada dalam lingkungan sekolah. Iklim kerja yang kondusif dibutuhkan agar para guru dapat melakukan pekerjaan dengan senang hati, penuh semangat, dan bergairah, sehingga hasil pekerjaannya akan dapat meraih prestasi yang cukup tinggi. Guru menganggap lingkungan kerja menyenangkan jika mereka dapat melakukan suatu yang bermanfaat dan menimbulkan rasa dihargai.

Moos (dalam Hardiyanto \& Subijanto, 2003) mengemukakan ada tiga dimensi yang digunakan untuk mengukur iklim kerja yang meliputi lingkungan fisik, psikis dan sosial yaitu: 1) dimensi hubungan; 2) dimensi pertumbuhan dan perkembangan pribadi; dan 3) dimensi perubahan dan perbaikan sistem. Dimensi hubungan mengukur sejauh mana keterlibatan guru di dalam suatu sekolah, bagaimana guru dapat saling mendukung dan membantu, serta sejauh mana mereka dapat mengekspresikan kemampuan mereka secara bebas dan terbuka. Adapun dimensi tersebut antara lain adalah kekompakan, kepuasan dan ketertiban. Dimensi pertumbuhan dan perkembangan pribadi berorientasi pada tujuan organisasi dalam mendukung pertumbuhan dan perkembangan pribadi pegawai dan motivasi diri. Yang termasuk pada dimensi diri adalah kesulitan, kecakapan, kemandirian, dan kompetisi. Adapun dimensi perubahan dan perbaikan sistem membicarakan bagaimana iklim kerja mendukung harapan, memperbaiki kontrol dan merespon perubahan dimensi yang termasuk adalah formalitas, demokrasi, kejelasan aturan, dan inovasi.

Dimensi lingkungan fisik adalah membicarakan bagaimana iklim kerja seperti kelengkapan sumber, kenyamanan, serta keamanan lingkungan kerja yang memengaruhi prestasi kerja guru. Adapun skala yang termasuk dalam dimensi ini diantaranya adalah kelengkapan sumber, keamanan dan keteraturan lingkungan serta kenyamanan lingkungan fisik. Welberg dalam Hardiyanto dan Subijanto (2003) menunjukkan bahwa hampir seluruh dimensi di atas berkorelasi penting dengan prestasi kerja. Sementara Murray (dalam Hadiyanto \& Subijanto, 2003) mengatakan bahwa tingkah laku dipengaruhi baik oleh kepribadian maupun oleh lingkungan eksternal. Ia mengajukan suatu model kebutuhan dan tekanan (proses) yang dapat dianalogikan seperti pribadi dan lingkungan. Kebutuhan pribadi mengacu pada motivasi individu untuk mencapai suatu tujuan tertentu, sedangkan lingkungan proses merupakan 
situasi eksternal yang mendukung atau bahkan menyebabkan kekacauan dalam mengungkapkan kebutuhan pribadi.

Dari beberapa pendapat yang telah dikutip di atas, maka dapat disintesis bahwa iklim kerja adalah kondisi, pengaruh maupun rangsangan dari luar yang meliputi pengaruh fisik, dan keadaan sosial yang memengaruhi prestasi kerja guru. Iklim adalah merupakan kualitas dari lingkungan kerja organisasi sosial dan aktivitas guru yang secara spontan memengaruhi kerja guru. Iklim kerja merupakan kombinasi antara pengaruh rangsangan dari luar yang dapat memengaruhi perilaku guru. Pengaruh tersebut antara lain: 1) pemenuhan kebutuhan rohani; 2) inisiatif individu; 3) toleransi terhadap tindakan dan tanggung jawab; 4) otonomi dan kebebasan; 5) menaruh kepercayaan dan kontrol; 6) simpatik dan memberi dukungan; 7) jujur dan menghargai; 8) kejelasan tujuan; 9) pekerjaan yang berisiko; 10) memperhatikan tempat kerja; 11) memahami pengembangan karir; 12) memahami perhatian terhadap pekerjaan.

\section{Metode Penelitian}

Penelitian ini bertujuan untuk memperoleh gambaran mengenai hubungan antara perilaku kepemimpinan dan iklim kerja baik sendiri-sendiri ataupun secara bersama-sama dengan prestasi kerja guru. Penelitian ini menggunakan metode survei dengan pendekatan korelasional. Dalam penelitian dikaji hubungan antara dua variabel bebas dengan satu variabel terikat. Kedua variabel bebas yang dimaksud adalah perilaku kepemimpinan $\left(\mathrm{X}_{1}\right)$; dan iklim kerja $\left(\mathrm{X}_{2}\right)$, sedangkan variabel terikatnya adalah prestasi kerja guru (Y). Populasi sasaran dalam penelitian ini keseluruhan guru SMA negeri di Kota Kendari dengan menggunakan multistage proporsional random sampling. Penelitian ini menggunakan tiga instrumen berupa kuesioner, yaitu: 1) instrumen prestasi kerja guru, 2) instrumen perilaku kepemimpinan, serta 3) instrumen iklim kerja.

Pada teknik analisis data, persyaratan analisis yang digunakan adalah uji normalitas, uji homogenitas, dan kelinieran regresi. Normalitas data diuji dengan menggunakan uji Lilliefors, dan uji homogenitas data dengan menggunakan uji Bartlett. Pengujian hipotesis penelitian menggunakan analisis regresi dan korelasi, yang meliputi: 1) regresi linear sederhana; 2) regresi ganda; 3) korelasi sederhana dan korelasi ganda.

\section{Hasil dan Pembahasan}

\subsection{Deskripsi Data}

Secara keseluruhan deskripsi skor ketiga variabel penelitian dapat dirangkum dalam tabel berikut: 
Tabel 1 Deskripsi skor variabel penelitian

\begin{tabular}{lcccc}
\hline & \multicolumn{4}{c}{ Statistik Dasar } \\
\cline { 2 - 5 } \multicolumn{1}{c}{ Jenis Data } & Rata-rata & $\begin{array}{c}\text { Simpangan } \\
\text { Baku }\end{array}$ & Modus & Median \\
& 93,922 & 51,03 & 93,3 & 94,01 \\
Prestasi kerja guru & 95,216 & 34,21 & 99,81 & 96,48 \\
Perilaku kepemimpinan & 93,451 & 29,57 & 91,26 & 93,57 \\
Iklim kerja &
\end{tabular}

\subsection{Pengujian Persyaratan Analisis Data}

Pengujian hipotesis pada penelitian ini dilakukan derngan menggunakan analisis regresi dan korelasi. Untuk keperluan ini perlu dilakukan uji persyaratan analisis korelasi dan regresi, yaitu uji normalitas dan homogenitas data.

Tabel 2 Rangkuman hasil normalitas data

\begin{tabular}{ccccc}
\hline Variabel & $\mathrm{n}$ & $\mathrm{L}_{\text {hitung }}$ & $\mathrm{L}_{\text {tabel }}$ & Kesimpulan \\
\hline $\mathrm{Y}$ & 51 & 0,0548 & 0,124 & Normal \\
$\mathrm{X} 1$ & 51 & 0,1078 & 0,124 & Normal \\
$\mathrm{X} 2$ & 51 & 0,1168 & 0,124 & Normal \\
\hline
\end{tabular}

Tabel 3 Hasil uji homogenitas varians data

\begin{tabular}{cccc}
\hline Varians $Y$ atas & $\chi_{\text {hitung }}^{2}$ & $\chi_{\text {tabel }}^{2}$ & Kesimpulan \\
\hline $\mathrm{X}_{1}$ & 25,098 & 27,587 & Homogen \\
$\mathrm{X}_{2}$ & 14,844 & 30,144 & Homogen \\
\hline
\end{tabular}

\subsection{Pengujian Hipotesis Penelitian}

Penelitian ini menguji empat hipotesis dengan menggunakan analisis regresi dan korelasi. Dalam penelitian ini terdapat satu variabel terkait yaitu prestasi kerja guru $(\mathrm{Y})$ dan dua variabel bebas, yaitu perilaku kepemimpinan $\left(\mathrm{X}_{1}\right)$ dan iklim kerja $\left(\mathrm{X}_{2}\right)$. Hasil-hasil pengujian hipotesis penelitian adalah sebagai berikut:

Hubungan Perilaku Kepemimpinan $\left(X_{1}\right)$ dengan Prestasi Kerja Guru $(Y)$

Hipotesis pertama yang diajukan dalam penelitian ini menyatakan bahwa terdapat hubungan positif antara perilaku kepemimpinan dengan prestasi kerja guru. Dari hasil pengujian regresi dan korelasi sederhana prestasi kerja guru (Y) dengan perilaku kepemimpinan (X1), diperoleh konstanta $a$ sebesar 41,441 dan koefisien arah regresi $b$ sebesar 0,551, sehingga hubungan antara kedua variabel tersebut ditunjukkan oleh persamaan 
garis regresi: $\hat{Y}=41,441+0,551 \mathrm{X}_{1}$. Untuk mengetahui derajat keberartian dan kelinearan persamaan garis regresi, maka dilakukan uji F. Untuk jelasnya hasil uji $\mathrm{F}$ atas signifikansi koefisien regresi dan kelinearan model regresi terdapat dalam tabel 4.

Tabel 4 ANAVA uji keberartian dan kelinearan model regresi $\hat{Y}=41,441+0,551 \mathrm{X}_{1}$

\begin{tabular}{|c|c|c|c|c|c|c|}
\hline \multirow{2}{*}{$\begin{array}{l}\text { Sumber } \\
\text { Varians }\end{array}$} & \multirow[b]{2}{*}{$\mathrm{dk}$} & \multirow[b]{2}{*}{$\mathrm{JK}$} & \multirow[b]{2}{*}{ RJK } & \multirow{2}{*}{$F_{\text {hitung }}$} & \multicolumn{2}{|c|}{$\mathrm{F}_{\text {tabel }}$} \\
\hline & & & & & $\begin{array}{c}\alpha= \\
0,05\end{array}$ & $\begin{array}{c}\alpha= \\
0,01\end{array}$ \\
\hline Total & 51 & 452436 & - & - & & \\
\hline Regresi (a) & 1 & 449884,31 & 449884,31 & & & \\
\hline Regresi (b/a) & 1 & 519,687 & 519,687 & $12,532 * *$ & 1,91 & 2,65 \\
\hline Sisa & 49 & 2031,999 & 41,469 & & & \\
\hline Tuna cocok & 16 & 978,67 & 61,167 & $1016 \mathrm{~ns}$ & 106 & 255 \\
\hline Galat/error & 33 & 1053,33 & 31,919 & $1,910^{-10}$ & 1,90 & 2,כנ \\
\hline
\end{tabular}

Hasil pengujian signifikansi regresi menunjukkan $F_{h}=12,532>F_{(0,01}$ : $1 / 43)=2,65$ dan hasil pengujian kelinearan regresi menunjukkan $F_{h}=1,916<$ $\mathrm{F}_{\mathrm{t}(0,01,16 / 33)}=2,55$, yang berarti regresi prestasi kerja guru $(\mathrm{Y})$ atas perilaku kepemimpinan $\left(\mathrm{X}_{1}\right)$ signifikan dan hubungan keduanya bersifat linear. Dengan demikian maka perilaku kepemimpinan merupakan salah satu prediktor prestasi kerja guru. Persamaan garis regresi $\hat{Y}=41,441+0,551 \mathrm{X}_{1}$ mengandung arti bahwa setiap kenaikan satu skor perilaku kepemimpinan akan menyebabkan kenaikan prestasi kerja guru sebesar 0,551 pada konstanta 41,441 .

Tabel 5 Uji signifikansi koefisien korelasi perilaku kepemimpinan $\left(\mathrm{X}_{1}\right)$ dengan prestasi kerja guru (Y)

\begin{tabular}{cccccc}
\hline \multirow{2}{*}{$\mathrm{N}$} & \multirow{2}{*}{ Korelasi } & \multicolumn{2}{c}{$\begin{array}{c}\text { Koefisien Korelasi } \\
\left(r_{\mathrm{y} 1}\right)\end{array}$} & $\mathrm{t}_{\text {hitung }}$ & \multicolumn{2}{c}{$\mathrm{T}_{\text {tabel }(\mathrm{dk}=49)}$} \\
\cline { 5 - 7 } & $\mathrm{X} 1$ dan $\mathrm{Y}$ & 0,451 & $4,26 * *$ & 1,645 & 2,326 \\
\hline ** & & &
\end{tabular}

**Sangat signifikan

Hasil pengujian keberartian koefisien korelasi menunjukkan bahwa hubungan antara perilaku kepemimpinan $\left(\mathrm{X}_{1}\right)$ dengan prestasi kerja $(\mathrm{Y})$ bersifat positif dan sangat signifikan. Dengan kata lain, semakin baik prestasi 
kerja guru. Dengan demikian maka hipotesis pertama terbukti bahwa terdapat hubungan positif antara perilaku kepemimpinan dengan prestasi kerja guru.

Hubungan antara perilaku kepemimpinan dengan prestasi kerja guru tetap positif dan sangat signifikan kendatipun variabel iklim kerja dikontrol melalui uji korelasi parsial. Untuk jelasnya korelasi parsial dapat dilihat Tabel 6.

Tabel 6 Korelasi $\mathrm{Y}$ atas $\mathrm{X}_{1}$ jika variabel $\mathrm{X}_{2}$ dikontrol

\begin{tabular}{|c|c|c|c|c|c|}
\hline \multirow{2}{*}{$\mathrm{N}$} & \multirow{2}{*}{$\begin{array}{c}\text { Korelasi } \\
\text { Pasial }\end{array}$} & \multirow{2}{*}{$\begin{array}{c}\text { Koefisien } \\
\text { Korelasi Parsial }\end{array}$} & \multirow{2}{*}{$\mathrm{t}_{\text {hitung }}$} & \multicolumn{2}{|c|}{$t_{\text {tabel }}$} \\
\hline & & & & 0,05 & 0,01 \\
\hline 51 & ry1.2 & 0,356 & $2,36 * *$ & 1,645 & 2,236 \\
\hline
\end{tabular}

Pengontrolan variabel iklim kerja memberi efek pada turunnya jumlah korelasi perilaku kepemimpinan dengan prestasi kerja guru dari 0,451 menjadi 0,356 . Uji signifikan koefisien korelasi parsial menunjukkan $t_{h}=2,36>t_{t(0,01 ; 47)}$ $=2,236$ yang berarti koefisien korelasi prestasi kerja guru dengan perilaku kepemimpinan adalah sangat signifikan jika iklim kerja dikontrol.

\section{Hubungan iklim kerja $\left(\mathrm{X}_{2}\right)$ dengan prestasi kerja guru(Y)}

Hipotesis kedua yang diajukan dalam penelitian ini menyatakan bahwa terdapat hubungan positif antara iklim kerja dengan prestasi kerja guru. Dari hasil pengujian regresi dan korelasi sederhana antara prestasi kerja $(\mathrm{Y})$ dengan iklim kerja $\left(\mathrm{X}_{2}\right)$, diperoleh konstanta $a$ sebesar 41,667 dan koefisien arah regresi $b$ sebesar 0,559 sehingga hubungan antara kedua variabel tersebut ditunjukkan oleh persamaan garis regresi: $\hat{Y}=41,667+0,559 \mathrm{X} 2$

Untuk mengetahui tingkat signifikansi koefisien regresi dan kelinieran modelregresi tersebut maka dilakukan uji $\mathrm{F}$. Untuk jelasnya hasil uji $\mathrm{F}$ atas signifikansi dan kelinearan model regresi terdapat dalam Tabel 7.

Hasil pengujian signifikansi regresi menunjukkan bahwa $F_{h}=10,842>$ $\mathrm{F}_{(0,01 ; 1 / 43)}=2,65$ dan hasil pengujian kelinearan regresi menunjukkan $F_{h}=$ $1,234<\mathrm{F}_{(0,01 ; 26 / 22)}=2,57$. Hal ini menunjukkan regresi prestasi kerja guru $(\mathrm{Y})$ atas iklim kerja $\left(\mathrm{X}_{2}\right)$ sangat signifikan dan hubungan keduanya bersifat linear. Dengan demikian, maka iklim kerja merupakan salah satu prediktor prestasi kerja guru.

Persamaan garis regresi $\hat{Y}=41,667+0,559 \mathrm{X}_{2}$ mempunyai arti bahwa setiap kenaikan satu skor Iklim Kerja akan menyebabkan kenaikan prestasi kerja guru sebesar 0,559 pada konstanta 41,667. 
Tabel 7 Tabel ANAVA uji signifikansi dan linearitas regresi $\hat{Y}=41,667+0,559 \mathrm{X}_{2}$

\begin{tabular}{|c|c|c|c|c|c|c|}
\hline \multirow{2}{*}{$\begin{array}{l}\text { Sumber } \\
\text { Varians }\end{array}$} & \multirow[b]{2}{*}{$\mathrm{Dk}$} & \multirow[b]{2}{*}{$\mathrm{JK}$} & \multirow[b]{2}{*}{ RJK } & \multirow[b]{2}{*}{$F_{\text {hitung }}$} & \multicolumn{2}{|c|}{$\mathrm{F}_{\text {tabel }}$} \\
\hline & & & & & $\begin{array}{c}\alpha= \\
0,05\end{array}$ & $\begin{array}{c}\alpha= \\
0,01\end{array}$ \\
\hline Total & 51 & 452436 & - & - & & \\
\hline Regresi (a) & 1 & 449884,314 & 449884,314 & & & \\
\hline Regresi (b/a) & 1 & 462,324 & 462,324 & $10,842 * *$ & 1,91 & 2,65 \\
\hline Sisa & 49 & 2089,362 & 42,640 & & & \\
\hline Tuna cocok & 17 & 797,346 & 46,903 & $1234^{\mathrm{ns}}$ & 104 & 257 \\
\hline Galat/error & 34 & 1292,02 & 38,000 & 1,254 & 1,94 & 2,91 \\
\hline
\end{tabular}

Tabel 8 Uji signifikansi koefisien korelasi iklim kerja $\left(\mathrm{X}_{2}\right)$ dengan prestasi kerja guru (Y)

\begin{tabular}{|c|c|c|c|c|c|}
\hline \multirow{2}{*}{$\mathrm{N}$} & \multirow{2}{*}{ Korelasi } & \multirow{2}{*}{$\begin{array}{l}\text { Koefisien Korelasi } \\
\left(\mathrm{r}_{\mathrm{y} 2}\right)\end{array}$} & \multirow{2}{*}{$\mathrm{t}_{\text {hitung }}$} & \multicolumn{2}{|c|}{$\mathrm{t}_{\text {tabel }(\mathrm{dk}=48)}$} \\
\hline & & & & 0,05 & 0,01 \\
\hline 51 & $\mathrm{X} 2$ dan $\mathrm{Y}$ & 0,426 & $3,93 * *$ & 1.645 & 2,235 \\
\hline
\end{tabular}

Hasil pengujian tersebut menunjukkan bahwa hubungan antara iklim kerja $\left(\mathrm{X}_{2}\right)$ dengan prestasi kerja guru $(\mathrm{Y})$ bersifat positif dan sangat signifikan. Dengan kata lain, semakin kondusif iklim kerja maka semakin tinggi prestasi kerja guru. Dengan demikian maka hipotesis kedua yang menyatakan, terdapat hubungan positif antar iklim kerja dengan prestasi kerja guru berterima.

Hubungan Perilaku Kepemimpinan (X1) dan Iklim kerja (X2) secara bersama-sama dengan Prestasi Kerja Guru $(Y)$

Hipotesis ketiga yang diajukan dalam penelitian ini menyatakan bahwa terdapat hubungan positif antara perilaku kepemimpinan dan iklim kerja secara bersama-sama dengan prestasi kerja guru. Dan hasil uji regresi dan korelasi jamak diperoleh nilai konstanta regresi $a_{o}$ sebesar 16,456 nilai koefisien regresi $a_{1}$ sebesar 0,40 dan nilai koefisien $a_{2}$ sebesar 0,421. Dengan demikian maka bentuk hubungan antara variabel bebas dengan variabel terikat dalam penelitian ini ditunjukan oleh persamaan garis regresi linier jamak: $\hat{Y}=$ $16,456+0,421 \mathrm{X} 1+0,400 \mathrm{X} 2$.

Untuk mengetahui derajat keberartian persamaan garis regresi jamak maka dilakukan uji F. Untuk jelasnya hasil uji $\mathrm{F}$ atas signifikansi koefisien regresi jamak terdapat dalam Tabel 9. 
Tabel 9 ANAVA Uji keberartian dan kelinearan model regresi $\hat{Y}=16,456+0,421 \mathrm{X}_{1}+0,400 \mathrm{X}_{2}$

\begin{tabular}{|c|c|c|c|c|c|c|}
\hline Sumber & \multirow{2}{*}{$\mathrm{Dk}$} & \multirow{2}{*}{$\mathrm{JK}$} & \multirow{2}{*}{ RJK } & \multirow{2}{*}{$F_{\text {hitung }}$} & \multicolumn{2}{|c|}{$\mathrm{F}_{\text {tabel }}$} \\
\hline Varians & & & & & $\begin{array}{c}\alpha= \\
0,05\end{array}$ & $\alpha=0,01$ \\
\hline Total & 50 & 2551,686 & - & - & & \\
\hline Regresi & 2 & 727,613 & 363,806 & 9 $573 * *$ & 3198 & 510 \\
\hline Sisa & 48 & 1824,074 & 38,002 & 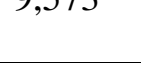 & $J, 170$ & \\
\hline
\end{tabular}

Dari hasil pengujian signifikansi regresi diperoleh $F_{\text {hitung }}=9,573>$ $\mathrm{F}_{(0,01 ; 2 / 48}=5.10$ yang berarti regresi ganda $\mathrm{Y}$ atas $\mathrm{X}_{1}$ dan $\mathrm{X}_{2}$ signifikan. Hal ini menunjukan bahwa prestasi kerja guru $(\mathrm{Y})$ atas perilaku kepemimpinan (X1) dan iklim kerja (X2) sangat signifikan. Hal ini berarti perilaku kepemimpinan dan iklim kerja secara bersama-sama merupakan prediktor prestasi kerja guru.

Persamaan garis regresi $\hat{Y}=16,456+0,421 \mathrm{X}_{1}+0,400 \mathrm{X}_{2}$ berarti bahwa setiap pertambahan 1 skor pada variabel perilaku kepemimpinan dan iklim kerja secara bersama-sama dapat menyebabkan pertambahan prestasi kerja guru sebesar 0,821 pada konstanta 16,456. Kekuatan hubungan antara variabel-variabel tersebut ditunjukkan oleh koefisien korelasi jamak sebesar 0,534. Uji signifikansi koefisien jamak terlihat pada tabel 10 .

Tabel 10 Uji keberartian koefisien korelasi jamak perilaku kepemimpinan $\left(\mathrm{X}_{2}\right)$ dan iklim kerja $\left(\mathrm{X}_{2}\right)$ secara bersama-sama dengan prestasi kerja guru (Y)

\begin{tabular}{cccccc}
\hline \multirow{2}{*}{$\mathrm{N}$} & \multirow{2}{*}{ Korelasi } & Koefisien & \multirow{2}{*}{$\mathrm{F}_{\text {hitung }}$} & \multicolumn{2}{c}{$\mathrm{F}_{\text {tabel }}$} \\
\cline { 6 - 7 } & & Korelasi Jamak & & 0,05 & 0,01 \\
\hline R1 & Ry.12 & 0,534 & 9,573 & $\mathbf{3 , 1 9 8}$ & $\mathbf{5 , 1 0}$ \\
\hline
\end{tabular}

**Sangat signifikan

Hasil pengujian menunjukkan bahwa hubungan antara perilaku kepemimpinan dan iklim kerja secara bersama-sama bersifat positif dan sangat signifikan dengan koefisien determinasi yaitu sebesar 0,285. Temuan ini menunjukkan bahwa semakin baik perilaku kepemimpinan dan kondusif iklim kerja secara bersama-sama maka akan semakin baik pula prestasi kerja guru, dimana $28,5 \%$ varians yang terjadi pada prestasi kerja guru dijelaskan secara bersama-sama oleh perilaku kepemimpinan dan iklim kerja melalui persamaan garis regresi: $\hat{Y}=16,456+0,421 \mathrm{X}_{1}+0,400 \mathrm{X}_{2}$. Hasil pengujian regresi dan 
korelasi jamak tersebut membuktikan bahwa hipotesis ketiga yang menyatakan terdapat hubungan positif antara perilaku kepemimpinan dan iklim kerja secara bersama-sama dengan prestasi kerja guru dapat diterima.

Berdasarkan hasil pengujian korelasi antara prestasi guru, perilaku kepemimpinan dan iklim kerja, ketiga hipotesis penelitian terbukti menolak $\mathrm{H}_{0}$. Variabel-variabel perilaku kepemimpinan $\left(\mathrm{X}_{1}\right)$ dan iklim kerja $\left(\mathrm{X}_{2}\right)$ berhubungan positif serta sangat signifikan dengan prestasi kerja guru (Y). Hubungan positif dan sangat signifikan antara variabel bebas dan variabel terikat dalam penelitian ini dijelaskan sebagai berikut.

Pertama, dari hasil analisis regresi dan korelasi sederhana atas variabel perilaku kepemimpinan dengan prestasi kerja guru diperoleh persamaan garis regresi $\hat{Y}=41,441+0,551 X_{1}$ dan korelasi sebesar 0,451 yang masing-masing sangat signifikan pada $\square=0,01$. Hal ini membuktikan bahwa perilaku kepemimpinan merupakan salah satu prediktor prestasi kerja guru. Kedua variabel ini berhubungan positif dan sangat signifikan, dimana 20,4\% varians yang terjadi pada prestasi kerja guru dapat dijelaskan oleh perilaku kepemimpinan melalui persamaan garis regresi $\hat{Y}=41,441+0,551 X_{1}$. Temuan ini menunjukkan bahwa perilaku kepemimpinan kepala sekolah dalam menggendalikan sekolahnya berhubungan erat dengan usahanya dalam membantu para guru agar dapat melakukan aktivitas sesuai dengan yang telah ditugaskan dan secara pribadi bertanggung jawab atas hasil kerja, pencapaian tujuan, dan penggunaan sumber daya tertentu sesuai dengan kewenangan (tanggung jawab) dalam rangka mewujudkan tujuan operasional sekolah. Dengan demikian, untuk mewujudkan prestasi kerja yang lebih baik maka salah satu faktor penentu yang harus diperhatikan adalah perilaku kepemimpinan. Artinya, jika seseorang kepala sekolah memiliki perilaku yang baik maka prestasi kerja guru akan baik pula.

Kedua, melalui analisis regresi dan korelasi sederhana atas variabel iklim kerja dengan prestasi kerja guru, diperoleh persamaan garis regresi $\hat{Y}=$ $41,667+0,559 \mathrm{X}_{2}$. dan koefisien korelasi sebesar 0,426 yang masing-masing sangat signifikan pada $\square=0,01$. Hal ini membuktikan bahwa iklim kerja merupakan salah satu prediktor prestasi kerja guru. Kedua variabel tersebut berhubungan positif dan sangat signifikan, dimana $18,1 \%$ varians yang terjadi pada prestasi kerja guru, dan dapat dijelaskan oleh iklim kerja melalui persamaan garis regresi $\hat{Y}=41,667+0,559 \mathrm{X}_{2}$. Iklim kerja yang kondusif dapat mewujudkan prestasi kerja guru yang lebih baik. Artinya, jika iklim kerja baik atau kondusif maka prestasi kerja guru akan cenderung baik. Tetapi apabila iklim kerja kurang kondusif atau kurang baik maka prestasi kerja akan cenderung menurun.

Ketiga, dari hasil analisis regresi dan korelasi jamak atas perilaku kepemimpinan dan iklim kerja secara bersama-sama dengan prestasi kerja guru, diperoleh persamaan garis regresi: $\hat{Y}=16,456+0,421 \mathrm{X}_{1}+0,400 \mathrm{X}_{2}$ dan 
koefisien korelasi sebesar 0,534 masing-masing signifikan pada $\square=0,01$. Variabel bebas dan variabel terikat tersebut berhubungan positif dan sangat signifikan, dimana $28,5 \%$ varians terjadi pada prestasi kerja guru, dan dapat dijelaskan secara bersama-sama mengenai perilaku kepemimpinan dan iklim kerja melalui persamaan garis regresi jamak: $\hat{Y}=16,456+0,421 \mathrm{X}_{1}+0,400 \mathrm{X}_{2}$. Temuan ini membuktikan bahwa variabel-variabel perilaku kepemimpinan dan iklim kerja secara bersama-sama merupakan prediktor prestasi kerja guru. Dengan demikian, untuk mewujudkan prestasi kerja guru yang lebih baik maka beberapa faktor penentu yang harus diperhatikan adalah perilaku kepemimpinan dan iklim kerja. Oleh karena itu, jika seorang kepala sekolah memiliki perilaku kepemimpinan positif dan iklim kerja yang kondusif maka prestasi kerja guru akan cenderung meningkat. Sebaliknya, jika seorang kepala sekolah memiliki perilaku kepemimpinan negatif dan iklim kerja yang tidak kondusif maka prestasi kerja guru akan cenderung menurun.

\section{Kesimpulan}

Perilaku kepemimpinan kepala sekolah dalam mengendalikan sekolah berhubungan erat dangan prestasi kerja guru. Perilaku kepemimpinan yang dimaksud merupakan usaha untuk membantu para guru agar dapat melakukan aktivitas sesuai dengan apa yang telah diberikan dan bertanggung jawab atas hasil kerja, pencapaian tujuan, dan penggunaan sumber daya tertentu sesuai dengan kewenangan dalam menjalankan tugasnya selaku guru untuk mewujudkan tujuan pendidikan.

Di sisi lain, iklim kerja merupakan salah satu prediktor prestasi kerja guru. Hal tersebut berupa Iklim yang kondusif dan menyenangkan. Untuk mewujudkan prestasi kerja guru yang lebih baik perlu memperhatikan iklim kerja yang mendukungsehingga prestasi kerja guru akan meningkat.

Perilaku kepemimpinan dan iklim kerja secara bersama-sama juga merupakan prediktor prestasi kerja guru. Dengan demikian, agar tercipta prestasi kerja guru yang lebih baik maka faktor yang harus diperhatikan adalah perilaku kepemimpinan dan iklim kerja. Dalam hal ini, terdapat korelasi antara ketiga variabel tersebut yang sejatinya dapat membantu terciptanya proses pembelajaran yang lebih baik.

\section{Daftar Pustaka}

Abdurrahman. (1993). Pengelolaan pengajaran. Ujung Pandang: Bintang Selatan.

Azhari, A. (2003). Supervisi rencana program pembelajaran. Jakarta: Ardadizya. 
Danim, S. (2004). Motivasi kepemimpinan dan efektivitas kelompok. Jakarta: Rineka Cipta.

Hersey, P., \& Blanchard, K. (1969). Management of organizational behavior: Utilizing human resources. New Jersey: Prentice-Hall.

Hardiyanto, \& Subijanto. (2003). Manajemen berbasis sekolah (MBS). Jurnal Pendidikan dan Kebudayaan, 40.

Ndaraha, T. (2003). Budaya organisasi. Jakarta: Rineka Cipta.

Nawawi, H. (2003). Kepemimpinan mengefektifkan organisasi. Yogyakarta: Gadjah Mada University Press.

Nurdin, H. S. (2005). Guru profesional dan implementasi kurikulum. Jakarta: Quantum Teaching.

Usman, M. U. (2000). Menjadi guru profesional. Bandung: Remaja Rosdakarya. 